\title{
Economic of the irrigated production of forage millet $^{1}$
}

\section{Viabilidade econômica da produção de milheto forrageiro irrigado}

\author{
Rogério Ricalde Torres ${ }^{2 *}$; Adroaldo Dias Robaina ${ }^{3}$; Marcia Xavier Peiter ${ }^{3}$; \\ Luis Humberto Bahú Ben; Wellington Mezzomo ${ }^{4}$; Jardel Henrique Kirchner5; \\ Tonismar dos Santos Pereira ${ }^{6}$; Taise Cristine Buske ${ }^{7}$; Gisele Aparecida Vivan ${ }^{8}$; \\ Leonita Beatriz Girardi ${ }^{9}$
}

\begin{abstract}
Irrigation is an agricultural technique that increases crop yield and reduces periods of forage shortage. However, this technique increases production costs, and the process is economically viable only when costs are lower than the financial return. Determining the technical and financial viability of irrigation is essential to assess the feasibility of forage production systems. Therefore, the objective of this study was to determine the technical and financial viability of irrigated producing of forage millet in different growing seasons in two microregions of the state of Rio Grande do Sul, Brazil. The water requirements of the growing seasons of 2012 to 2017 in the microregions of Santiago and Santa Maria varied and affected the cost of irrigation. The irrigated production of forage millet increased the total average cost by $13.42 \%$ and increased the financial return by $43.03 \%$ and $22.49 \%$ in Santiago and Santa Maria, respectively.
\end{abstract}

Keywords: Estimated animal gain. Production cost. Conventional sprinkler irrigation. Pennisetum americanum $\mathrm{L}$.

\section{Resumo}

A irrigação é uma técnica que visa garantir altos rendimentos e reduzir períodos de escassez forrageira. Com a inclusão desta técnica, há um incremento no custo de produção, devendo este ser inferior aos rendimentos decorrentes de sua utilização para garantir a opção pelo uso. A determinação da viabilidade técnica e financeira da utilização da irrigação é imprescindível para avaliar os sistemas produtivos

Parte da tese de doutorado do primeiro autor.

2 Prof., Instituto Federal de Educação, Ciência e Tecnologia do Rio Grande do Sul, IFRS, Campus Vacaria, Vacaria, RS, Brasil. E-mail: rogerio.torres@vacaria.ifrs.edu.br

3 Profs., Programa de Pós-Graduação em Engenharia Agrícola, Universidade Federal de Santa Maria, UFSM, Santa Maria, RS, Brasil. E-mail: diasrobaina@gmail.com; mpeiter@gmail.com

4 Discentes de Doutorado, Programa de Pós-Graduação em Engenharia Agrícola, UFSM, Santa Maria, RS, Brasil. E-mail: luishumbertoben@gmail.com; wellingtonmezzomo@gmail.com

5 Prof., Instituto Federal de Educação, Ciência e Tecnologia do Rio Grande do Sul, IFRS, Campus Ibirubá, Ibirubá, RS, Brasil. E-mail: jardel.kirchner@ibiruba.ifrs.edu.br

6 Prof., Universidade Federal de Pelotas, UFPel, Pelotas, RS, Brasil. E-mail: tonismarpereira@gmail.com

7 Prof ${ }^{\text {, }}$ Instituto Federal de Educação, Ciência e Tecnologia de Santa Catarina, Campus Santa Rosa do Sul, Santa Rosa do Sul, SC, Brasil. E-mail: taise.buske@ifc.edu.br

8 Profa $^{a}$, Instituto Federal de Educação, Ciência e Tecnologia Sul-Rio-Grandense, IFSul, Campus Bagé, Bagé, RS, Brasil. E-mail: giselevivan@ifsul.edu.br

9 Prof $^{a}$, Instituto de Desenvolvimento Educacional do Alto Uruguai, IDEAU, Campus Passo Fundo, Passo Fundo, RS, Brasil. E-mail: lbgirardi@hotmail.com

* Author for corespondence 
forrageiros. Dessa forma, o objetivo deste trabalho foi determinar a viabilidade técnica e financeira do uso da irrigação, na produção de forragem de milheto, para diferentes safras agrícolas e em duas microregiões do Estado do Rio Grande do Sul. Verificou-se que as demandas hídricas das diferentes cinco safras agrícolas 2012-2017, para as microrregiões de Santiago e Santa Maria são variáveis e influenciam nos custos da irrigação. A inclusão da irrigação na produção de forragem de milheto aumentou o custo total, em média, em $13,42 \%$, porém proporcionou aumento do retorno econômico de $43,03 \%$ e $22,49 \%$ para as respectivas microrregiões.

Palavras-chave: Estimativa de ganho animal. Custo de produção. Aspersão convencional fixa. Pennisetum americanum $L$.

\section{Introduction}

Irrigation is an agricultural technique that allows supplying quality feed to herds throughout the year. Moreover, this technique may reduce the effects of water scarcity by guaranteeing high forage yields (OLIVEIRA et al., 2015; KIRCHNER et al., 2017; KOETZ et al., 2017). Although irrigation may improve livestock production systems, the economic analysis of irrigation is essential to assess its sustainability, and high yields are necessary to ensure the viability of the investment (SOARES et al., 2015). In this respect, the analysis of production costs helps farmers plan investments, optimize the invested capital, and maximize profits (RICHETTI, 2014).

The increase in productivity does not necessarily lead to an increase in profits for farmers because the financial return relative to the investment is not always satisfactory (FERNANDES, 2012). Therefore, feasibility studies are vital for adequate decision-making by farmers, reducing the uncertainties on the expected financial return.

The technical and economic sustainability can be determined by quantifying the level of production relative to the number of inputs necessary to reach the desired level of production (GOMES et al., 2013). The conversion of forage dry matter into animal weight depends, among other factors, on the supply of animal feed. Heringer and Carvalho (2002) indicated that the recommended forage supply was $4 \%$, with an estimated consumption of $2.5 \mathrm{~kg}$ dry matter (DM) per $100 \mathrm{~kg}$ live weight (LW) (NATIONAL RESEARCH COUNCIL, 1984), and feed rejection or loss of $37 \%$ of the consumed feed.

Krinchev et al. (2018) have demonstrated that cattle raising is essential for the Brazilian agribusiness, where pastures are considered the primary sources of feed for the herds (MANETTI FILHO et al., 2018). Pinheiro (2002) has shown that pasture irrigation in Brazil, depending on local climatic conditions, has a variable financial return, from a profit of $\mathrm{R} \$ 770.00$ to a loss of $\mathrm{R} \$$ 140.00 ha $^{-1}$ year ${ }^{-1}$. Animal weight gain can affect the profitability of productive systems. Glienke (2012) found that the average daily gain was variable in millet pastures under grazing, with gains of $<0.500$, $0.501-1.000,1,001-1.500$, and $>1.500 \mathrm{~kg} \mathrm{day}^{-1}$ for $10.76 \%, 57.89 \%, 23.42 \%$, and $8.23 \%$ of pastures, respectively. The author pointed out that the intake of millet DM by animals ranged from $5 \mathrm{~kg}_{\text {day }}{ }^{-1}$ to approximately $7.4 \mathrm{~kg}$ day $^{-1}$, with an average stocking rate of 5.06 $\mathrm{AU} \mathrm{ha}^{-1}$ and weight gain per area of 8.15 $\mathrm{kg} \mathrm{ha}^{-1}$ day $^{-1}$. Moojen et al. (1999) found that the average daily gain was $0.55-0.76 \mathrm{~kg} \mathrm{day}^{-1}$ in millet pastures subjected to nitrogen doses with a forage supply of $10 \%$. Pacheco et al. (2014) evaluated the production of millet and sudangrass and found that the stocking rates were 1741.10 and $1881.70 \mathrm{~kg}$ ha${ }^{1}$, respectively, with an average daily gain of 1.04 and $0.96 \mathrm{~kg}$ animal $^{-1} \mathrm{day}^{-1}$ and LW gain (LWG) per area of 4.18 and $4.55 \mathrm{~kg} \mathrm{ha}^{-1}$, respectively.

Considering the need for the economic assessment of irrigated systems for forage production, the objective of this study was to determine the production costs and assess the technical and financial feasibility of irrigated production of forage millet. 


\section{Materials and Methods}

The cost-benefit ratios of non-irrigated and irrigated millet production were compared between five growing seasons (2012-2013, 2013-2014, 2014-2015, 2015-2016, and 2016-2017) in the microregions of Santiago and Santa Maria, Rio Grande do Sul, Brazil. The conversion of millet forage production in kilograms of LW and cost estimates were made on the basis of the irrigation requirement of each crop.

\section{Determination of irrigation requirement}

The irrigation requirement (IR) and the number of irrigations (NI) required during the crop cycle were determined by measuring the daily net balance of water inflow and outflow considering the effective precipitation (EP) as input and the reference evapotranspiration (ETo) as output. The difference between ETo and EP in 7-day periods was considered the IR of the crop. For measuring EP, the flow coefficient of 0.30 proposed by Millar (1974) was used, and the EP corresponded to $70 \%$ of the total precipitation recorded in the period.

The historical series recorded in the meteorological stations from the National Climate Monitoring Network were obtained from INMET for Santiago and Santa Maria in the period from 2012 to 2017. The harvest period started on November 15 and lasted 140 days. The ETo was obtained daily using the Penman-Monteith equation, as described by Allen et al. (1998).

\section{Estimation of forage yield}

Forage yield (FY) (kg of DM ha ${ }^{-1}$ ) was determined using the production function (waterculture), which was obtained in field experiments in the growing season of 2014-2015 and 2015-2016 in Santiago and Santa Maria, respectively. Millet yield per hectare $\left(\mathrm{kg} \mathrm{DM} \mathrm{ha}^{-1}\right)$ was determined for the IL of $0,25,50,75,100$, and $125 \%$ of ETo.
Millet forage production was determined experimentally in the two study regions for 140 days at cutting heights of $15 \mathrm{~cm}$ from the soil at 50 , 80,110 , and 140 days after sowing. The irrigation system used was conventional sprinkling with a fixed irrigation period of 7 days and IL of $0,25,50$, 75,100 , and $125 \%$ of ETo. The adopted equation was $\mathrm{Y}=11040.0409+52.4104 \mathrm{X}-0.1342 \mathrm{X}^{2}$ for Santiago and $Y=11355.9413+47.6096 \mathrm{X}$ $0.1617 \mathrm{X}^{2}$ for Santa Maria, and the coefficient of determination $\left(\mathrm{R}^{2}\right)$ was 0.96 and 0.93 , respectively, where Y was the FY ( $\mathrm{kg}$ of DM ha $\mathrm{D}^{-1}$ ) at four cutting heights, and $\mathrm{X}$ was the irrigation regime (\%ETo).

\section{Estimation of $L W G$}

The expected production of millet forage allowed calculating the potential stocking rate (SR), in which:

$$
S R=\frac{F Y}{P . F S}(1)
$$

where SR is stocking rate $\left(\mathrm{kg} \mathrm{LW} \mathrm{ha} \mathrm{a}^{-1}\right), \mathrm{FY}$ is the forage yield $\left(\mathrm{kg} \mathrm{LW} \mathrm{ha}^{-1}\right), \mathrm{P}$ is the period (days), and FS is forage supply ( $\mathrm{kg}$ of DM day ${ }^{-1} \mathrm{~kg}$ of $\left.\mathrm{LW}^{-1}\right)$.

The FY was obtained in field experiments. The $\mathrm{P}$ used in field experiments was 90 days. The FS was $4 \mathrm{~kg}$ DM per $100 \mathrm{~kg} \mathrm{LW}$, as detailed by Heringer and Carvalho (2002).

The SR values allowed estimating the number of animals per unit area, and the SR multiplied by the average daily weight gain (ADWG) and the grazing period yielded the LWG per animal according to the equation:

$$
L W G=\frac{S R}{L W} \cdot A D W G \cdot P(2)
$$

where LWG is the live weight gain ( $\left.\mathrm{kg} \mathrm{LW} \mathrm{ha} \mathrm{h}^{-1}\right)$, $\mathrm{LW}$ is the live weight ( $\mathrm{kg}$ of $\left.\mathrm{LW}^{-1}\right)$, and ADWG is the average daily weight gain ( $\mathrm{kg}$ of $\left.\mathrm{LW} \mathrm{ha} \mathrm{h}^{-1} \mathrm{day}^{-1}\right)$.

The LW used for the simulations was $300 \mathrm{~kg}$. The ADWG was $1 \mathrm{~kg}$, as proposed by Glienke (2012) and Pacheco et al. (2014). 


\section{Gross revenue}

The gross revenues of the estimated production of LW in each irrigation regime in the two regions were obtained using the LWG multiplied by the average price of the animal kilogram.

$$
G R=L W G \cdot S P(3)
$$

where GR is the gross revenue $\left(\mathrm{R} \$ \mathrm{ha}^{-1}\right)$ and $\mathrm{SP}$, is the selling price of the product $\left(\mathrm{R} \$ \mathrm{~kg}^{-1}\right.$ of $\left.\mathrm{LW}\right)$

An average $\mathrm{SP}$ of $\mathrm{R} \$ 5.00 \mathrm{~kg}^{-1}$ was considered in this study according to the values determined in the region in 2017 (SANTA RITA REMATES, 2017).

\section{Production costs and financial return}

The costs were evaluated considering the fixed and variable costs of the forage production system (related or not to irrigation) according to functions of net benefit to the farmer proposed by Martin et al. (1989), Broner and Lambert (1989), Mannocchi and Mecarelli (1994), Frizzone and Andrade Junior (2005), and Santos Junior et al. (2015).

The fixed costs unrelated to irrigation (FCUI) involved all necessary operations and inputs (machine hours, tractor hours, man hours, tillage, seeds, sowing, herbicides, pesticides, and soil) according to the methodology established by CONAB (2010). The costs related to irrigation (CRI) were divided into fixed costs (FCRI) and variable costs (VCRI), and these variables were measured using a conventional sprinkler irrigation system designed according to the methodology proposed by Biscaro (2009).

The system was designed using the following parameters: suction height of $5 \mathrm{~m}$; discharge height of $15 \mathrm{~m}$; slope of the central line and lateral lines of $2 \mathrm{~m}$; sprinkler elevation of $2 \mathrm{~m}$, length of discharge pipe of $100 \mathrm{~m}$, length of suction pipe of $10 \mathrm{~m}$. The total irrigated area was the distance between the sprinklers at the end of the study site plus twice $60 \%$ of the reach of the sprinklers, resulting in an area of 1.28 ha, and the obtained values were corrected for one unit of area (1 ha). The prices were obtained from existing equipment, including irrigation pipes with the usual diameter and the lowest possible nominal pressure for each sector (lateral, central, discharge, and suction lines). Only one pipe diameter was selected for each sector. The lateral lines in operation were controlled using PVC valves.

The FCRI were calculated using the following equation (CONAB, 2010):

$$
\mathrm{FCRI}=\mathrm{CD}+\mathrm{CI}+\mathrm{IC}(4)
$$

where FCRI is the fixed CRI $\left(\mathrm{R} \$ \mathrm{ha}^{-1}\right)$, the $\mathrm{CD}$ is the cost of depreciation of the irrigation system $(\mathrm{R} \$$ $\left.\mathrm{ha}^{-1}\right), \mathrm{CI}$ is the cost with interest on the invested capital ( $\left.\mathrm{R} \$ \mathrm{ha}^{-1}\right)$, and IC is the insurance cost of the components of the irrigation system $\left(\mathrm{R} \$ \mathrm{ha}^{-1}\right)$.

The CD was calculated using the following equation (CONAB, 2010):

$$
C D=[(V N C-R V) / S L h] . T H W h(5)
$$

where VNC is the purchase value of the new component $\left(\mathrm{R} \$ \mathrm{ha}^{-1}\right), \mathrm{RV}$ is the residual value of the component $\left(\mathrm{R} \$ \mathrm{ha}^{-1}\right)$, SLh is the service life of component (h), and THWh is the total hours worked by component $h$.

Th RV was calculated as $20 \%$ of the VNC. The service life was 20 years (CONAB, 2010).

The CI were calculated considering a rate of remuneration of $6.0 \%$ per year on the average value of the equipment according to the equation:

$$
C I=\{[((V N C \cdot Q M) / 2) / W C] . T H W h\} . J(6)
$$

where QM is the quantity of the material, $\mathrm{WC}$ is the working capacity of material (h), and $\mathrm{J}$ is the rate of return.

The IC values were $0.35 \%$ of the VNC (CONAB, 2010), as follows:

$$
\mathrm{IC}=(\mathrm{VNC} / 2) \cdot 0.35 \text {. (THWh/SLh) (7) }
$$


The VCRI were obtained by the cost of sprinkler irrigation, manpower, and system maintenance, according to the equation:

$$
\mathrm{VCRI}=\mathrm{VCE}+\mathrm{VCL}+\operatorname{VCEM}(8)
$$

where VCRI is the variable CRI (R\$), VCE is the variable cost of electric energy (R\$), VCL is the variable cost of labor used in irrigation ( $R \$)$, and VCEM is the variable cost of equipment maintenance $(\mathrm{R} \$)$.

The VCE was calculated considering the pump power and the period of application of sprinkler irrigation, according to the equation:

$$
\text { VCE = E.CE. IL (9) }
$$

where $\mathrm{E}$ is the energy required to apply one millimeter of water $\left(\mathrm{kW} \mathrm{h} \mathrm{mm}^{-1}\right), \mathrm{CE}$ is the cost of electric energy $\left(\mathrm{R} \$ \mathrm{~kW}^{-1} \mathrm{~h}^{-1}\right)$, and IL is the irrigation level (mm).

The power needed to apply one millimeter of water by irrigation was determined using the data for one hectare.

The CE was $0.32 \mathrm{R} \$ \mathrm{~kW} \mathrm{~h}^{-1}$ considering the price in the green tariff set by the National Electricity Agency (Agencia Nacional de Energia ElétricaANEEL) (RIO GRANDE ENERGIA, 2017).

The ILs were measured using the net balance of water inflow and outflow based on the historical series.

The VCL was calculated using the proposed time of 0.5 hours per hectare in each system sector by irrigation (MAROUELLI; SILVA, 2011) considering an hourly pay of one minimum wage (CONAB, 2010) according to the equation:

$$
V C L=N I \cdot N S \cdot 0.5 \cdot M W / 220(10)
$$

where NI is the number of irrigations, NS is the number of sectors of the irrigation system, and MW is the minimum wage $(\mathrm{R} \$)$.

The NI was determined using the net balance of water inflow and outflow considering the historical series.

The NS of the irrigation system was six. The MW was R\$ 1,175.15 (BRASIL, 2017).

The VCEM was calculated over $1 \%$ of the value of the irrigation system plus $10 \%$ of the VCE (CONAB, 2010) according to the equation:

$$
V C E M=V N .0 .01 \mathrm{VCE} / 10)(11)
$$

The net return in different production systems [without irrigation and at different IL (25, 50, 75,100 , and $125 \%$ of ETo)] was obtained by the equation:

$$
\mathrm{NR}=\mathrm{GR}-\mathrm{FCUI}-\mathrm{FCRI}-\mathrm{VCRI}(12)
$$

where NR is the net return to the farmer $\left(\mathrm{R} \$ \mathrm{ha}^{-1}\right)$, GR is the gross revenue ( $\left.\mathrm{R} \$ \mathrm{ha}^{-1}\right), \mathrm{FCUI}$ is the fixed costs unrelated to irrigation ( $\left.\mathrm{R} \$ \mathrm{ha}^{-1}\right)$, FCRI is the fixed CRI, and VCRI is the variable CRI $\left(\mathrm{R} \$ \mathrm{ha}^{-1}\right)$.

The NR was determined at different IL.

\section{Results and Discussion}

The analysis of the historical series allowed determining the EPs, NI, and water regimes (\% ETo). The NI necessary in the growing seasons ranged from 6 to 10 in Santiago region from 6 to 12 in Santa Maria (Table 1). The NI affected the variable costs of labor (Table 2). 
Table 1. Effective precipitation $(\mathrm{mm})$, number of irrigations, and water requirement $(\mathrm{mm})$ at different irrigation levels (\%ETo) for producing forage millet in the growing seasons of 2012-2013, 2013-2014, 2014-2015, 2015-2016, and 2016-2017 in the microregions of Santiago and Santa Maria, Rio Grande do Sul, Brazil.

\begin{tabular}{|c|c|c|c|c|c|c|c|c|}
\hline \multirow{2}{*}{, } & \multirow{2}{*}{$\begin{array}{c}\text { Treatment } \\
(\% \text { ETo })\end{array}$} & \multicolumn{7}{|c|}{ Growing season } \\
\hline & & $2012 / 2013$ & $2012 / 2013$ & $2014 / 2015$ & $2015 / 2016$ & $2016 / 2017$ & Mean & SD \\
\hline \multicolumn{9}{|c|}{ Santiago } \\
\hline EP & & 600 & 535 & 578 & 608 & 760 & 616 & 85 \\
\hline \multirow[t]{3}{*}{$\mathrm{Ni}^{2}$} & & 8 & 10 & 9 & 7 & 6 & 8 & 2 \\
\hline & 25 & 24 & 44 & 17 & 22 & 24 & 26 & 11 \\
\hline & 50 & 47 & 89 & 34 & 45 & 48 & 53 & 21 \\
\hline \multirow[t]{3}{*}{$\mathrm{IL}$} & 75 & 73 & 133 & 51 & 67 & 72 & 79 & 31 \\
\hline & 100 & 97 & 177 & 67 & 90 & 96 & 106 & 42 \\
\hline & 125 & 122 & 223 & 84 & 112 & 121 & 132 & 52 \\
\hline \multicolumn{9}{|c|}{ Santa Maria } \\
\hline EP & & 570 & 514 & 599 & 612 & 740 & 607 & 83 \\
\hline \multirow[t]{3}{*}{$\mathrm{Ni}^{2}$} & & 10 & 12 & 8 & 6 & 9 & 9 & 2 \\
\hline & 25 & 41 & 65 & 32 & 30 & 38 & 41 & 14 \\
\hline & 50 & 82 & 129 & 64 & 60 & 76 & 82 & 28 \\
\hline \multirow[t]{3}{*}{ IL } & 75 & 124 & 194 & 97 & 90 & 114 & 124 & 41 \\
\hline & 100 & 165 & 258 & 129 & 121 & 151 & 165 & 55 \\
\hline & 125 & 206 & 323 & 161 & 151 & 189 & 206 & 69 \\
\hline
\end{tabular}

EP, effective precipitation in the period ( $\mathrm{mm}$ ); NI, number of irrigations in the period; IL, irrigation level in the period ( $\mathrm{mm}$ ).

The water loss for an irrigation regime of $125 \%$ of ETo (in which the maximum technical efficiency was obtained) ranged from 84 to $221 \mathrm{~mm}$ and from 150 to $323 \mathrm{~mm}$ in Santiago and Santa Maria, respectively, and this parameter differentially affected the VCE and VCEM. It should be noted that the water loss was higher in Santa Maria, with a 5-year average of $206 \mathrm{~mm}$.

Dantas et al. (2016) found that the yield of Brachiaria brizantha grown in autumn and winter was higher at irrigation levels of 267 and $269 \mathrm{~mm}$, respectively. The authors reported that irrigation could provide higher and stable forage production. Kirchner et al. (2017) studied forage sorghum in the region of Santiago, Rio Grande do Sul, and found that the evapotranspiration demand was $563 \mathrm{~mm}$ and, even with an EP of $618 \mathrm{~mm}$, an irrigation level of $179 \mathrm{~mm}$ was required, confirming the irregular distribution of precipitation, which resulted in instability in production. 


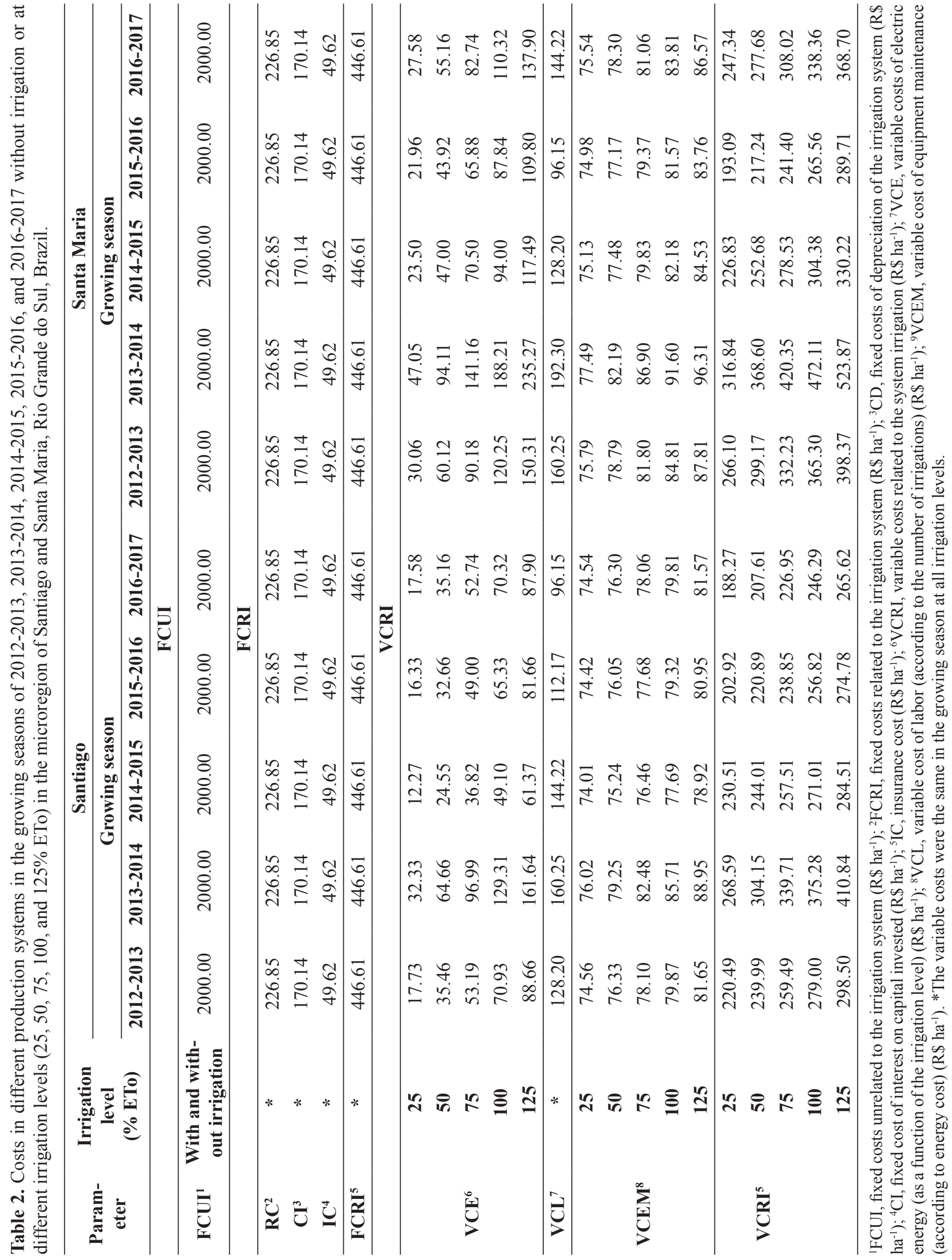


The estimated production of forage millet in the two study regions and SR in the forage production system with and without irrigation are shown in Figure 1. The irrigation regime of $125 \%$ ETo, which allowed increased forage production in the two study regions, provided higher SRs and, consequently, higher LWG. The comparison between the productive systems without irrigation and those with an irrigation regime of $125 \%$ of ETo indicated that forage production ranged from 11,040 to 15,494 and from 11,356 to $14,781 \mathrm{~kg}$ of $\mathrm{DM} \mathrm{ha}^{-1}$ in Santiago and Santa Maria, respectively. The SR ranged from 3,067 to 4,304 $\mathrm{kg} \mathrm{LW} \mathrm{ha}^{-1} \mathrm{LW}$ in Santiago and from 3,154 to 4,106 kg LW ha ${ }^{-1}$ in Santa Maria.
The comparison of the treatments indicated that the higher was the irrigation level, the higher was the SR per unit area and, consequently, the higher was the LW gain. Montagner et al. (2008) evaluated the performance of beef heifers in millet pastures and found relatively lower SRs (3,120 to 2,542 kg LW ha ${ }^{-1}$ ). Pacheco et al. (2014) evaluated the production of millet pastures continuously grazed by cows destined for slaughter and found a relatively lower SR, corresponding to $1,741 \mathrm{~kg} \mathrm{LW}$ $\mathrm{ha}^{-1}$, and this lower value can be attributed to lower FY, which might be due to the different experimental conditions used in these studies.

Figure 1. Estimated production of forage millet $\left(\mathrm{kg} \mathrm{ha}^{-1}\right)$ and stocking rate $\left(\mathrm{kg}\right.$ live weight ha ${ }^{-1}$ day $\left.^{-1}\right)$ in production systems without irrigation or at different irrigation levels $(25,50,75,100$, and $125 \%$ of ETo) in the microregion of Santiago and Santa Maria, Rio Grande do Sul, Brazil.

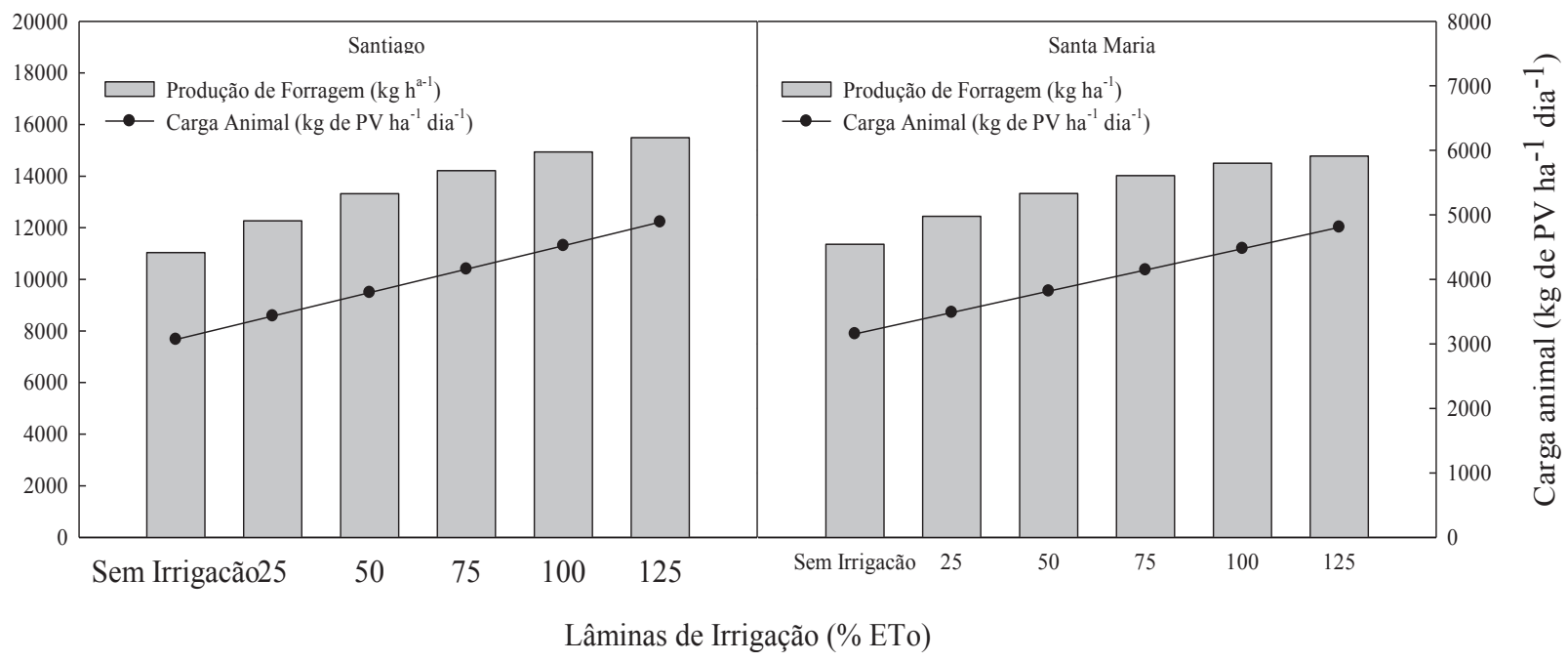

In both study sites, forage production and SR were increased as water availability was increased, and the most significant difference between these regions was at an irrigation level of $125 \%$ of ETo, which was $4.83 \%$ higher in the Santiago region (Figure 1).

The costs of the production systems are shown in Table 2. The components of the total fixed cost (FCNRI and FCRI) were the same, whereas the components of the VCRI varied according to the NI and ILs. The VCRI were lowest in the growing season of 2016-2017 in Santiago (R\$265.62 per hectare), which is justified by the lower NI during the harvest period (six) (Table 1). The VCRI were highest in the growing season of 2013-2014 in Santa Maria (R\$ 523.87 per hectare), which is attributed to the higher NI during the harvest period (12) and higher ILs (323.01 mm). 
The inclusion of the irrigation system increased the total cost of the productive system by an average of $13.42 \%$, and the variation was lowest $(10.20 \%)$ in the growing season of 2016-2017 in the region of Santiago and highest $(20.76 \%)$ in the growing season of 2013-2014 in Santa Maria. The CD was lower than that found by Marouelli and Silva (2011), corresponding to $\mathrm{R} \$ 601.67 \mathrm{ha}^{-1}$ for conventional fixed irrigation systems.

The costs unrelated to irrigation were similar to those obtained by Martins et al. (2016), wherein the annual average costs for maize using drip irrigation was $\mathrm{R} \$ 2,325.00 \mathrm{ha}^{-1}$ (total costs unrelated to irrigation). The FCRI and VCRI found by these authors were R $\$ 1,848.75 \mathrm{ha}^{-1}$ and $\mathrm{R} \$ 118.65 \mathrm{ha}^{-1}$ respectively, and these values were higher and lower than those found in the present study, respectively. This difference can be attributed to the type of irrigation system, which usually has a higher VNC and a lower operating cost.
Previous studies have shown that the cost of forage production systems is high. Dantas et al. (2017) found that the annual cost of irrigated production of Indian fig for forage was R \$ 7,447.80 $\mathrm{ha}^{-1}$. In contrast, Pompeu et al. (2014) reported that the cost of production of millet for silage was $\mathrm{R} \$$ $6,409.90 \mathrm{ha}^{-1}$.

Table 3 shows that the production cost per ton of millet, at an IL of $125 \%$ ETo, was relatively lower in Santiago. This is because this region presented a relatively higher average irrigated production (Figure 1) and lower production costs (Table 2). The comparison of the average cost in each study region indicated that irrigation at $125 \%$ of ETo decreased the cost per ton of forage DM from R\$ 181,16 to R $\$ 177.71$ ton $^{-1}$ in Santiago but increased the cost from R $\$ 176.12$ to $R \$ 191.39$ ton $^{-1}$ in Santa Maria. The lower cost per ton in the non-irrigated system in Santa Maria can be attributed to the low level of production in the field due to a large amount of rainfall in the period and higher demand for irrigation, which increased the VCRI.

Table 3. Production cost per ton of millet forage $\left(\mathrm{R} \$\right.$ ton $\left.^{-1}\right)$ in different production systems in the growing seasons of 2012-2013, 2013-2014, 2014-2015, 2015-2016, and 2016-2017 without irrigation or at different irrigation levels (25, $50,75,100$, and 125\% ETo) in the microregion of Santiago and Santa Maria, Rio Grande do Sul, Brazil.

\begin{tabular}{cccccccc}
\hline \multirow{2}{*}{$\begin{array}{c}\text { Irrigation level } \\
\text { (\%ETo) }\end{array}$} & \multicolumn{7}{c}{ Growing season } \\
\cline { 2 - 8 } & $\mathbf{2 0 1 2 - 2 0 1 3}$ & $\mathbf{2 0 1 3 - 2 0 1 4}$ & $\mathbf{2 0 1 4 - 2 0 1 5}$ & $\mathbf{2 0 1 5 - 2 0 1 6}$ & $\mathbf{2 0 1 6 - 2 0 1 7}$ & Mean & SD \\
\hline Without irrigation & 181.16 & 181.16 & 181.16 & 181.16 & 181.16 & 181.16 & 0.00 \\
$\mathbf{2 5}$ & 217.43 & 221.35 & 218.25 & 216.00 & 214.80 & 217.57 & 2.50 \\
$\mathbf{5 0}$ & 201.62 & 206.44 & 201.92 & 200.19 & 199.19 & 201.87 & 2.78 \\
$\mathbf{7 5}$ & 190.36 & 196.00 & 190.22 & 188.90 & 188.07 & 190.71 & 3.11 \\
$\mathbf{1 0 0}$ & 182.45 & 188.89 & 181.91 & 180.96 & 180.26 & 182.90 & 3.46 \\
$\mathbf{1 2 5}$ & 177.17 & 184.42 & 176.26 & 175.64 & 175.05 & 177.71 & 3.83 \\
\hline & & \multicolumn{7}{c}{ Santa Maria } & & & \\
\hline Without irrigation & 176.12 & 176.12 & 176.12 & 176.12 & 176.12 & 176.12 & 0.00 \\
$\mathbf{2 5}$ & 217.97 & 222.05 & 214.82 & 212.11 & 216.47 & 216.68 & 3.71 \\
$\mathbf{5 0}$ & 205.95 & 211.16 & 202.46 & 199.81 & 204.34 & 204.74 & 4.25 \\
$\mathbf{7 5}$ & 198.25 & 204.53 & 194.42 & 191.77 & 196.52 & 197.10 & 4.81 \\
$\mathbf{1 0 0}$ & 193.93 & 201.29 & 189.72 & 187.05 & 192.07 & 192.81 & 5.40 \\
$\mathbf{1 2 5}$ & 192.48 & 200.97 & 187.87 & 185.13 & 190.47 & 191.39 & 6.03 \\
\hline
\end{tabular}


The expected profit per hectare at an IL of $125 \%$ of ETo was higher than that at the other ILs because of the greater difference between costs and gross revenue (Figure 2). However, it is of note that the increase in forage supply from higher losses or consumption but the maintenance of LW, ADWG, and the cost of the kg of LW decreases or even nulls the expected profit per hectare.

Animal weight also affected the FY because in cases in which heavier animals were used, the number of heads to be allocated per unit area was decreased, resulting in lower gain per unit area. In turn, the profit was higher if the ADWG or the SP of LW was increased. Gottschall et al. (2013) found that the ADWG at the finishing phase of bulls in millet pastures was $1.43 \mathrm{~kg}$ of LW, which corresponded to an average weight gain $43 \%$ higher than that found in the present study, resulting in gross revenue of the same proportion.

Figure 2. Average live weight gain ( $\mathrm{kg}$ of live weight ha $\left.{ }^{-1}\right)$, fixed cost [FCUI + FCRI) $\left.\left(\mathrm{R} \$ \mathrm{ha}^{-1}\right)\right]$, total costs [FCUI + FCRI + VCRI $\left.\left(\mathrm{R} \$ h^{-1}\right)\right]$, gross revenue $\left(\mathrm{R} \$ \mathrm{ha}^{-1}\right)$ in different production systems and growing seasons in the microregion of Santiago and Santa Maria, Rio Grande do Sul, Brazil.

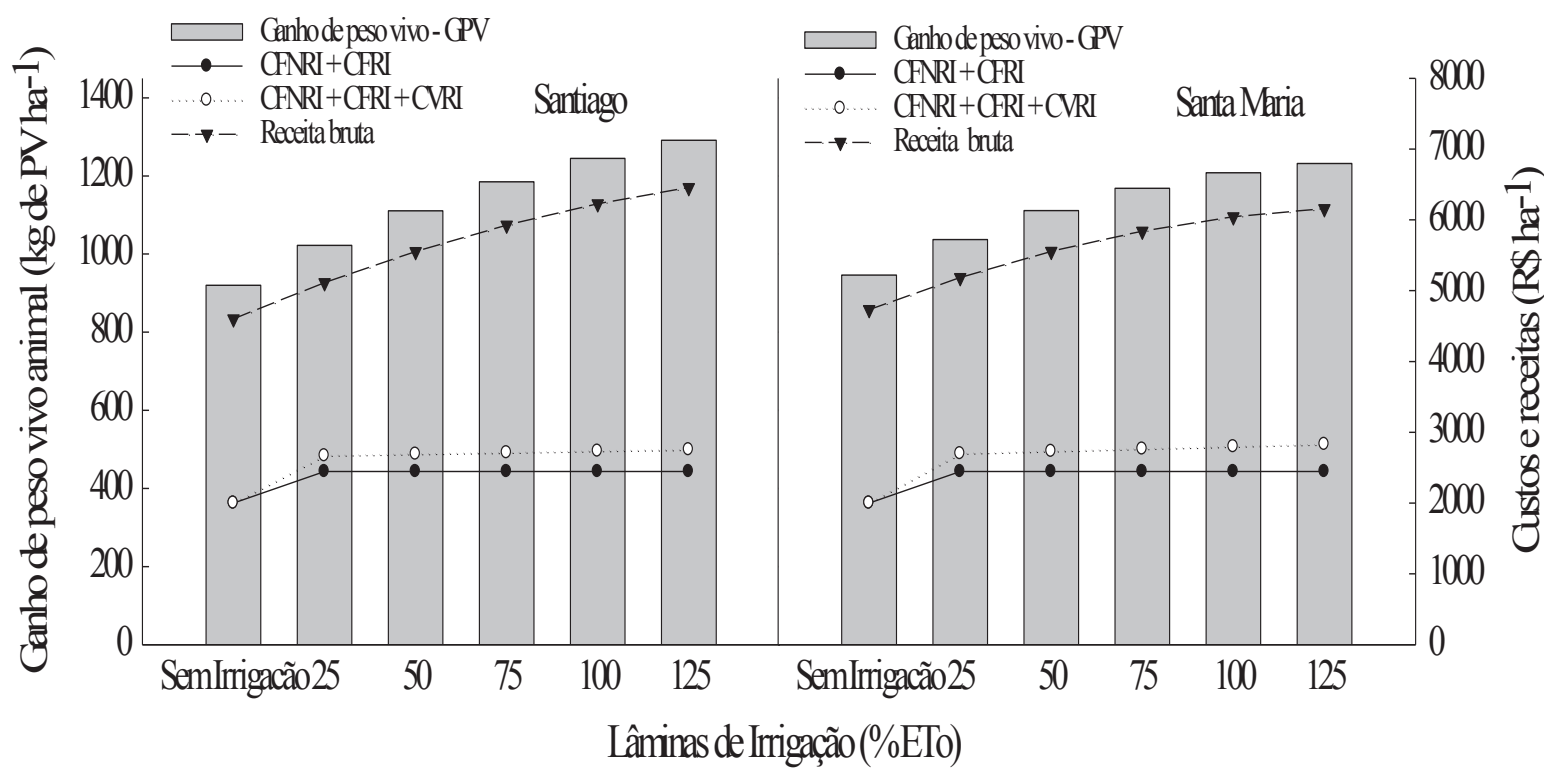

The average ADWG in Santiago for treatments without irrigation and with an IL of $125 \%$ of ETo was $920 \mathrm{~kg} \mathrm{LW} \mathrm{ha} \mathrm{h}^{-1}$ and 1,291 $\mathrm{kg} \mathrm{LW} \mathrm{ha}{ }^{-1}$, respectively (Figure 2). The average increase in ADWG per unit area using irrigation at this IL was $40 \%$. In Santa Maria, the average ADWG was 946 to $1,231 \mathrm{~kg} \mathrm{LW}$ $\mathrm{ha}^{-1}$, corresponding to an increase of $30 \%$.

The ADWG found in this study was higher than that reported by Restle et al. (2002). These authors evaluated the performance of beef steers fed different forage species and found that the ADWG using a millet crop was $639.9 \mathrm{~kg} \mathrm{LW} \mathrm{ha}^{-1}$ in a period of 98 days, and the ADWG per animal was 1.19 $\mathrm{kg}$. This difference can be attributed to the lower DM production and the higher supply of forage, corresponding to $9,039 \mathrm{~kg} \mathrm{ha}^{-1}$ and $6 \%$, respectively.

Similar to the results of this study, Ribeiro et al. (2008) reported that the average annual weight gain $\left(1,112.5-1,312.0 \mathrm{~kg}\right.$ of LW ha $\left.{ }^{-1}\right)$ was increased by approximately $18 \%$, and this parameter was affected by the irrigation of elephant grass and Mombaça grass in periods of drought and rain. 
The average fixed cost and total fixed cost in each treatment and region using an IL of $125 \%$ of ETo were R \$ 2,737.39 and R 2,812.71 ha- in Santiago and Santa Maria, respectively (Figure 2). These costs are higher than those found by Soares et al. (2015), whereby the total cost of three different irrigated production systems was $\mathrm{R} \$ 1,626.93, \mathrm{R} \$$ 2,004.86, and R $2,101.59 \mathrm{ha}^{-1}$.
The expected financial return in different irrigation regimens and growing seasons in the two study regions is shown in Table 4. The average profit was relatively higher in Santiago, with an increase of $43.02 \%$ (IL of $125 \%$ of ETo) relative to the non-irrigated production system because of higher forage production (Figure 1) and lower VCRI (Table 2). The average profit increase in Santa Maria considering the five growing seasons was $22.49 \%$.

Table 4. Expected profit per hectare $\left(\mathrm{R} \$ \mathrm{ha}^{-1}\right)$ and cost-benefit ratio in different production systems in the growing seasons of 2012-2013, 2013-2014, 2014-2015, and 2016-2017 without irrigation or at different irrigation levels (25, $50,75,100$, and $125 \%$ ETo) in the microregion of Santiago and Santa Maria, Rio Grande do Sul, Brazil.

\begin{tabular}{ccccccccc}
\hline $\begin{array}{c}\text { Irriga- } \\
\text { tion level } \\
\text { (\%ETo) }\end{array}$ & $\mathbf{2 0 1 2 / 2 0 1 3}$ & $\mathbf{2 0 1 3 / 2 0 1 4}$ & $\mathbf{2 0 1 4 / 2 0 1 5}$ & $\mathbf{2 0 1 5 / 2 0 1 6}$ & $\mathbf{2 0 1 6 / 2 0 1 7}$ & Mean & SD & $\begin{array}{c}\text { Cost-benefit } \\
\text { ratio } \\
\text { Mean }\end{array}$ \\
\cline { 2 - 9 } & \multicolumn{7}{c}{ Santiago } \\
\hline $\begin{array}{c}\text { Without } \\
\text { irrigation }\end{array}$ & $2,600.02$ & $2,600.02$ & $2,600.02$ & $2,600.02$ & $2,600.02$ & $2,600.02$ & 0.00 & 2.30 \\
$\mathbf{2 5}$ & $2,459.99$ & $2,411,88$ & $2,449,97$ & $2,477.55$ & $2,492.20$ & $2,458.32$ & 30.61 & 1.93 \\
$\mathbf{5 0}$ & $2,881.58$ & $2,817.42$ & $2,877.56$ & $2,900.68$ & $2,913.96$ & $2,878.24$ & 37.05 & 2.08 \\
$\mathbf{7 5}$ & $3,233.28$ & $3,153.06$ & $3,235.26$ & $3,253.92$ & $3,265.83$ & $3,228.27$ & 44.16 & 2.20 \\
$\mathbf{1 0 0}$ & $3,515.08$ & $3,418.80$ & $3,523.07$ & $3,537.26$ & $3,547.79$ & $3,508.40$ & 51.65 & 2.29 \\
$\mathbf{1 2 5}$ & $3,726.99$ & $3,614.65$ & $3,740.98$ & $3,750.70$ & $3,759.86$ & $3,718.64$ & 59.39 & 2.36 \\
\hline & & & \multicolumn{7}{c}{ Santa Maria } & & & \\
\hline Without & $2,731.64$ & $2,731.64$ & $2,731.64$ & $2,731.64$ & $2,731.64$ & $2,731.64$ & 0.00 & 2.37 \\
irrigation & & & & & & & \\
$\mathbf{2 5}$ & $2,488.83$ & $2,438.09$ & $2,528.10$ & $2,561.84$ & $2,507.58$ & $2,504.89$ & 46.12 & 1.93 \\
$\mathbf{5 0}$ & $2,825.37$ & $2,755.94$ & $2,871.85$ & $2,907.29$ & $2,846.85$ & $2,841.46$ & 56.70 & 2.05 \\
$\mathbf{7 5}$ & $3,077.69$ & $2,989.56$ & $3,131.39$ & $3,168.52$ & $3,101.90$ & $3,093.81$ & 67.43 & 2.13 \\
$\mathbf{1 0 0}$ & $3,245.79$ & $3,138.97$ & $3,306.71$ & $3,345.53$ & $3,272.73$ & $3,261.95$ & 78.25 & 2.17 \\
$\mathbf{1 2 5}$ & $3,329.67$ & $3,204.16$ & $3,397.81$ & $3,438.32$ & $3,359.34$ & $3,345.86$ & 89.12 & 2.19 \\
\hline
\end{tabular}

Azevedo and Saad (2009) found that pasture irrigation was economically feasible in nine of ten cities in Brazil, and the net revenue was comparatively higher in Boa Vista, Roraima state, at $\mathrm{R} \$ 735.85 \mathrm{ha}^{-1}$. In contrast, the city of Sete Lagoas, Minas Gerais, presented a negative annual profit of $\mathrm{R} \$ 139.22 \mathrm{ha}^{-1}$.
Faria et al. (2015) compared different pasture recovery systems for dairy cattle production in the municipality of Bambuí, Minas Gerais, and reported that the integrated crop-livestock-forest system was economically viable, with a positive balance of $\mathrm{R} \$$ $11,269.70$ ha $^{-1}$, whereas the crop-livestock system and a grass pasture system were not feasible, with 
negative balances of $\mathrm{R} \$ 2,766.40$ and $\mathrm{R} \$ 3,143.80$ $\mathrm{ha}^{-1}$, respectively (these values correspond to the cash flow for a period of 12 years).

The balances found by Manetti Filho et al. (2012) were relatively lower. These authors evaluated the financial return of fattening heifers on irrigated pastures and found that the gross return, production cost, and net revenue were $\mathrm{R} \$ 1,960.00 \mathrm{ha}^{-1}, \mathrm{R} \$$ 1,375.89 $\mathrm{ha}^{-1}$, and R $\$ 584.11 \mathrm{ha}^{-1}$, respectively, in a period of 140 days.

The analysis of the cost-benefit ratio of the productive systems indicated that all analyzed systems were viable, and the obtained benefits were higher than the costs (Table 4). In Santiago, the costbenefit ratio was higher for the IL of $125 \%$ of ETo, with a profit of R \$ 2.36 for each R $\$ 1.00$ invested. In Santa Maria, the profit for the same IL was R\$ 2.19, and the profit was comparatively higher $(\mathrm{R} \$ 2.37)$ in the non-irrigated system, which was more efficient. This result indicates that productive systems with high IL are economically efficient, although the cost-benefit ratio was higher in the non-irrigated system in the Santa Maria microregion. Similar values were found by Montagner et al. (2008), wherein the cost-benefit ratio of rearing heifers on millet pastures varied from 2.6 to 3.3.

Alves Junior et al. (2018) demonstrated that the irrigation of soybean, corn, and tomato crops was economically feasibility, with an average benefitcost ratio of 2.10 for central pivot irrigation. Andrade et al. (2014) found that the cost-benefit ratio of sheep production was relatively lower, varying from 1.00 to 1.12 .

\section{Conclusions}

The water demands in different geographical regions and growing seasons were variable and affected the variable cost of irrigation of millet.

The irrigated production of forage millet increased the average total cost by $13 \%$.
Fixed conventional sprinkler irrigation was economically feasible, and the financial return in the regions of Santiago and Santa Maria was 43\% and $22 \%$, respectively.

The cost-benefit ratio of millet production at different irrigation levels indicated that all evaluated systems, including rainfed systems, were economically feasible.

\section{Acknowledgments}

We are grateful to the Graduate Program in Agricultural Engineering of the Federal University of Santa Maria for the technical and financial support; the funding agencies CAPES and CNPq for providing scholarships; and to the Federal Institute of Education, Science, and Technology of Rio Grande do Sul for research funding.

\section{References}

ALLEN, R. G.; PEREIRA, L. S.; RAES, D.; SMITH M. Evapotranspiración del cultivo Guías para la determinación de los requerimientos de agua de los cultivos. Rome: FAO, 1998. 300 p. (FAO. Irrigation and drainage paper, 56).

ALVES JUNIOR, J.; SALES, D. L. A.; PEREIRA, R. M.; RODRIGUES, W. D. M.; CASAROLI, D.; EVAGELISTA, A. W. P. Viabilidade ecônomica da irrigação por pivô central nas culturas de soja, milho e tomate, em diferentes demandas hídricas. Pesquisa Agropecuária Pernambucana, Recife, v. 22, e201703, 2018. Acesso em: 8 jun. 2018.

ANDRADE, I. R. A. de; CÂNDIDO, M. J. D.; POMPEU, R. C. F. F.; GUIMARÃES, V. P.; SILVA, L. V. da; EVANGELISTA, M. E. S. Desempenho produtivo e econômico do confinamento de ovinos utilizando diferentes fontes proteicas na ração concentrada. Revista Brasileira de Saúde e Produção Animal, Salvador, v.15, n. 3, p. 717-730, jul./set. 2014. Disponível em: $<$ http:// www.scielo.br/pdf/rbspa/v15n3/a20v15n3.pdf $>$. Acesso em: 6 dez. 2017.

AZEVEDO, L. P. de; SAAD, J. C. C. Irrigação de pastagens via pivô central, na bovinocultura de corte. Revista Irriga, Botucatu, v. 14, n. 4, p. 492-503, out./ dez. 2009. Disponível em: <http://200.145.6.238/ 
bitstream/handle/11449/71168/2-s2.0-73549114883. pdf? sequence $=1 \&$ isAllowed $=\mathrm{y}>$. Acesso em: $6 \mathrm{dez}$. 2017.

BRASIL. Lei $\mathrm{n}^{\circ} 14.987$, de 3 de maio de 2017. Dispõe sobre o reajuste dos pisos salariais no âmbito do Estado do Rio Grande do Sul para as categorias profissionais que menciona, com fundamento na Lei Complementar Federal n. ${ }^{\circ} 103$, de 14 de julho de 2000, que autoriza os Estados e o Distrito Federal a instituir o piso salarial a que se refere o inciso $\mathrm{V}$ do art. $7 .^{\circ}$ da Constituição Federal, por aplicação do disposto no parágrafo único do seu art. 22. Porto Alegre: Palácio Piratini, 3 de maio de 2017. Diário Oficial [da] República Federativa do Brasil, Rio Grande do Sul, n. 083, 04 maio 2017, p. 1-3. Disponível em: <http:/www.al.rs.gov.br/filerepository/repLegis/ arquivos/LEI\%2014.987.pdf>. Acesso em: 3 out. 2017.

BISCARO, G. A. Sistemas de irrigação por aspersão. Dourados: Editora da UFGD, 2009. 134 p.

BRONER, B. I.; LAMBERT, J. Optimal scheduling of irrigation machines. I: Model development. Journal of Irrigation and Drainage Engineering, Reston, v. 115, n. 5, p. 862-879, 1989.

COMPANHIA NACIONAL DE ABASTECIMENTO CONAB. Custos de produção agrícola: a metodologia da CONAB. Brasília: CONAB, 2010. 60 p.

DANTAS, G. de F; FARIA, R. T. de; SANTOS, G. O.; DALRI, A. B.; PALARETTI, L. F. Produtividade e qualidade da brachiaria irrigada no outono/inverno. Engenharia Agrícola, Jaboticabal, v. 36, n. 3, p. 469481, mai./jun. 2016. Disponível em: <http://www. scielo.br/scielo.php? script $=$ sci arttext\&pid $=$ S0100$69162016000300469 \& \operatorname{lng}=p t \& t \operatorname{lng}=p t>$. Acesso em: 26 set. 2017.

DANTAS, G. de F.; LIMA, G. F. da C.; MOTA, E. P. da. Viabilidade econômica da produção de palma forrageira irrigada e adensada no semiárido Potiguar. Revista iPecege, Piracicaba, v. 3, n. 1, p. 59-74, 2017. Disponível em: <https://revista.ipecege.com/Revista/ article/view/122/75>. Acesso em: 6 dez. 2017.

FARIA, C. M. A. de; SILVA, M. L. da; FERREIRA, L. R.; de OLIVEIRA NETO, S. N.; SALLES, T. T. Análise econômica de sistemas de recuperação e manutenção de pastagens com gado de leite. Reflexões Econômicas, Santa Cruz, v. 1, n. 1, p. 85-103, abr./set. 2015. Disponível em: <http://periodicos.uesc.br /index.php/ reflexoeseconomicas/article/view/824/776>. Acesso em: 6 dez. 2017.

FERNANDES, L. M. Retorno financeiro e risco de preço da cultura do feijão irrigado via pivô central na região noroeste de minas gerais. Informações Econômicas, São
Paulo, v. 42, n. 1, p. 41-53, 2012. Disponível em: <http:// www.iea.sp.gov.br/ftpiea/publicacoes/IE/2012/tec40112.pdf>. Acesso em: 6 dez. 2017.

FRIZZONE, J. A.; ANDRADE JUNIOR, A. S. de. (Ed.). Planejamento da irrigação: análise de decisão de investimento. Brasília: EMBRAPA Informação Tecnológica, 2005. 626 p.

GLIENKE, C. L. Estudo da recria de novilhas de corte em pastagens cultivadas de verão. 2012. Tese (Doutorado em Zootecnia) - Universidade Federal de Santa Maria, Santa Maria.

GOMES, E. P.; JORDAN, R. A.; MOTOMIYA, A. V. de A.; PADUA, J. B.; BISCARO, G. A.; GEISENHOFF, L. $\mathrm{O}$. Análise econômica e viabilidade energética da cultura do feijoeiro comum sob irrigação. Revista Brasileira de Engenharia Agrícola e Ambiental, Campina Grande, v. 17, n. 8, p. 835-842, 2013. Disponível em: <http://www. scielo.br/pdf/rbeaa/v17n8/06.pdf $>$. Acesso em: $6 \mathrm{dez}$. 2017.

GOTTSCHALL, C. S.; SILVA, L. R. da; TOLOTTI, F. Avaliação do desempenho biológico de bovinos de corte terminados sobre pastagens de azevém (Lolium multiflorum) e milheto (Pennisetum glaucum). Veterinária em Foco, Canoas, v. 10, n. 2, p. 178-185. jan./jun. 2013. Disponível em: <http://www.periodicos. ulbra.br/index.php/veterinaria/article/view/1138/852>. Acesso em: 6 dez. 2017.

HERINGER, I.; CARVALHO, P. C. de F. Ajuste da carga animal em experimentos de pastejo uma nova proposta. Ciência Rural, Santa Maria, v. 32, n. 4, p. 675-679, 2002. Disponível em: <http://www.scielo.br/ pdf/cr/v32n4/ a21v32n4.pdf>. Acesso em: 6 dez. 2017.

KIRCHNER, J. H.; ROBAINA, A. D.; PEITER, M. X.; MEZZOMO, W.; TORRES, R. R.; GIRARDI, L. B.; PIMENTA, B. D.; ROSSO, R. B.; PEREIRA, A. C.; LOREGIAN, M. V. Variation of leaf area index of the forage sorghum under different irrigation depths in dynamic of cuts. African Journal of Agricultural Research, Nairóbi, v. 12, n. 2, p. 111-124, 2017. Available at: <http://www.academicjournals.org/journal /AJAR/ article-full-text-pdf/07BC8B762364>. Accessed at: 11 ago. 2017.

KOETZ, M.; BÄR, C. S. L. E. L.; PACHECO, A. B.; CASTRO, W. J. R. de; CRISOSTOMO, W. L.; SILVA, E. M. B. da. Produção e eficiência no uso da água do capim paiaguás sob tensões de água no solo. Revista Brasileira de Agricultura Irrigada, Fortaleza, v. 11, n. 1, p. 12231232, 2017. Disponível em: <http://www.inovagri.org. br/revista/index.php/rbai/article/view/571/pdf_330>. Acesso em: 18 jul. 2017. 
KRINCHEV, A. F. B.; BUMBIERIS JUNIOR, V. H.; GONÇALVES, J. R. S.; LIMA, L. G.; BRIDI, A. M.; RIBEIRO, E. L. de A. Productive performance of Nellore steers on rotational grazing on Marandu grass and Convert HD 364 grass. Semina: Ciências Agrárias, Londrina, v. 39, n. 4, p. 1627-1638, 2018. Available at: $<$ http://www.uel.br/revistas/uel/index.php/semagrarias/ article/view/29241/23984>. Accessed at: 10 set. 2018.

MANETTI FILHO, J.; HERNANDEZ, F. B. T.; CORAMORI, P. H. Engorda de novilhas com pasto irrigado no interior de São Paulo. In: CONGRESSO NACIONAL DE IRRIGAÇÃO E DRENAGEM CONIRD, 22., 2012, Cascavel. Anais... Cascavel: ABID, 2012.

MANETTI FILHO, J.; OLIVEIRA, C. M. G. de; CARAMORI, P. H.; NAGASHIMA, G. T.; HERNANDEZ, F. B. T. Cold tolerance of forage plant species. Semina: Ciências Agrárias, Londrina, v. 39, n. 4, p. 1469-1476, 2018. Available at: <http://www. uel.br/revistas/uel/index.php/semagrarias/article/view/ 31070/23968>. Accessed at: 10 sep. 2018.

MANNOCCHI, B. F.; MECARELLI, P. Optimization analysis of deficit irrigation systems. Journal of Irrigation and Drainage Engineering, Reston, v. 120, n. 3, p. 484503, 1994.

MAROUELli, W. A.; SILVA, W. L. C. Seleção de sistemas de irrigação para hortaliças. 2. ed. Brasília: EMBRAPA Hortaliças, 2011. 20 p. (Circular técnica, 11).

MARTIN, D. L.; GILLEY, J. R.; SUPALLA, R. J. Evaluation of irrigation planning decisions. Journal of Irrigation and Drainage Engineering, Reston, v. 115, n. 1, p. 58-77, 1989.

MARTINS, J. D.; PETRY, M. T.; RODRIGUES, G. C.; CARLESSO, R. Viabilidade econômica da irrigação deficitária em milho irrigado por gotejamento. Revista Irriga, Botucatu, p. 150-165, 2016. Edição especial, Grandes Culturas. Disponível em: <http://revistas.fca. unesp.br/index.php/irriga/article/view/1865/1437>. Acesso em: 6 dez. 2017.

MILLAR, A. A. Drenagem de terras agrícolas. Petrolina: Sudene, 1974. 164 p.

MONTAGNER, D. B.; ROCHA, M. G. da; SANTOS, D. T. dos; GENRO, T. C. M.; QUADROS, F. L. F. de; ROMAN, J.; POTTER, L.; BREMM, C. Manejo da pastagem de milheto para recria novilhas de corte. Ciência Rural, Santa Maria, v. 38, n. 8, p. 2293-2299, nov. 2008. Disponível em: <http://www.scielo.br/pdf/ cr/ v38n8/a31v38n8.pdf>. Acesso em: 6 dez. 2017.

MOOJEN, E. L.; RESTLE, J.; LUPATINI, G. C.; de MORAES, A. G. Produção animal em pastagem de milheto sob diferentes níveis de nitrogênio. Pesquisa Agropecuária Brasileira, Brasília, v. 34, n. 11, p. $2145-$ 2149, nov. 1999. Disponível em: <https://www.alice. cnptia.embrapa.br/bitstream/doc/101092/1/ pab20096. pdf $>$. Acesso em: 6 dez. 2017.

NATIONAL RESEARCH COUNCIL - NRC. Nutrient requeriments of beef cattle. $6^{\text {th }}$ ed. Washington: National Academy of Science, 1984. 90 p.

OLIVEIRA, E. M. de; OLIVEIRA FILHO, J. da C.; OLIVEIRA, R. A. de; OLIVEIRA, R. M. de; CECON, P. R.; CÓSER, A. C. Efeito da aplicação de diferentes lâminas de irrigação e doses de nitrogênio e potássio na produção do capim Tanzânia. Revista Ambiente e Água, Taubaté, v. 10, n. 3, jul./set. 2015. Disponível em: $<$ http://www.scielo.br/pdf/ambiagua/v10n3/1980-993Xambiagua-10-03-00698.pdf $>$. Acesso em: 22 set. 2017.

PACHECO, R. P.; ALVES FILHO, D. C.; BRONDANI, I. L.; NORNBERG, J. L.; PIZZUTI, L. A. D.; CALlegaro, A. M. Características produtivas de pastagens de milheto ou capim sudão submetidas ao pastejo contínuo de vacas para o abate. Ciência Animal Brasileira, Goiânia, v. 15, n. 3, p. 266-276, jul./set. 2014. Disponível em: <http://www.scielo.br/pdf/cab/v15n3/ a04v15n3.pdf $>$. Acesso em: 6 dez. 2017.

PINHEIRO, V. D. Viabilidade econômica da irrigação de pastagem de capim-tanzânia em diferentes regiões do Brasil. 2002. Dissertação (Mestrado em Agronomia) - Escola Superior e Agricultura Luiz de Queiroz, Universidade de São Paulo, Piracicaba.

POMPEU, R. C. F. F.; ANDRADE, I. R. A. de; SOUZA, H. A. de; GUEDES, F. L.; OLIVEIRA, L. S.; TONUCCI, R. G.; MARTINS, E. C. Produtividade e custos de produção de silagem para alimentação de ovinos a partir de sorgo, milheto e girassol - safra 2013. Sobral: EMBRAPA, 2014. (Circular técnica, 44). Disponível em: <https://www.infoteca.cnptia.embrapa.br/bitstream/ doc/990036/1/CT44.pdf>. Acesso em: 6 dez. 2017.

RESTLE, J.; ROSO, C.; AITA, V.; NORNBERG, J. L.; BRONDANI, I. L.; CERDÓTES, L.; CARRILHO, C. de O. Produção animal em pastagem com gramíneas de estação quente. Revista Brasileira de Zootecnia, Viçosa, MG, v. 31, n. 3, p. 1491-1500, 2002. Suplemento. Disponível em: <http://www.scielo.br/pdf/rbz/ v31n3s0/13106.pdf>. Acesso em: 6 dez. 2017.

RIBEIRO, E. G.; FONTES, C. A. de. A.; PALIERAQUI, J. G. B.; MARTINS, C. E.; CÒSER, A. C.; SANTANA, N. de F. Influência da irrigação durante as épocas seca e chuvosa na taxa de lotação, no consumo e no desempenho de novilhos em pastagens de capim-elefante e capimmombaça. Revista Brasileira de Zootecnia, Viçosa, MG, v. 37, n. 9, p. 1546-1554, 2008. Disponível em: <http:// 
www.scielo.br/ pdf/rbz/v37n9/a05v37n9.pdf $>$. Acesso em: 6 dez. 2017.

RICHETTI, A. Viabilidade econômica da cultura da soja na safra 2014/2015, em Mato Grosso do Sul. Dourados: EMBRAPA, 2014. (Comunicado técnico, 194). Disponível em: <https://ainfo.cnptia.embrapa.br/ digital/bitstream/item/105124/1/COT2013194.pdf >. Acesso em: 6 dez. 2017.

RIO GRANDE ENERGIA. Tarifas, taxas e tributos. - RGE SUL. Porto Alegre: [s.n.], 2017. Disponível em: <https://www.rgesul.com.br/clientes-residenciaiscomerciais/Paginas/informacoes/tarifas-taxas-tributos. aspx $>$. Acesso em: 3 out. 2017.

SANTA RITA REMATES. Cotações. médias dos últimos 4 remates, separados por categoria. São Sepé, 23 de novembro de 2017. São Sepé: [s.n.], 2017. Disponível em: <http://santaritaremates.com.br/cotacoes.php $>$. Acesso em: 23 nov. 2017.
SANTOS JUNIOR, J. L. C. dos; FRIZZONE, J. A.; PAZ, V. D. da S. Water use optimization through alternative water depths in the Formoso Irrigation District. Revista Brasileira de Engenharia Agrícola e Ambiental, Campina Grande, v. 19, n. 7, p. 621-629, 2015. Disponível em: $<$ http://www.scielo.br/pdf/ rbeaa/v19n7/1415-4366rbeaa-19-07-0621.pdf>. Acesso em: 6 dez. 2017.

SOARES, J. C. R.; BARCELLOS, J. O. J.; QUEIROZ FILHO, L. A. V.; OIAGEN, R. P.; CANOZZI, M. E. A.; CAMARGO, C. M.; DRUMOND, L. C. D.; BRACCINI NETO, J. Avaliação econômica da terminação de bovinos de corte em pastagem irrigada. Brazilian Journal of Veterinary and Animal Sciences, Belo Horizonte-MG, v. 67, n. 4, p. 1096-1104, 2015. Disponível em: <http://www.scielo.br/pdf/abmvz/v67n4/ 0102-0935-abmvz-67-04-01096.pdf >. Acesso em: 6 dez. 2017. 
